\title{
Corpos femininos volumosos e estética: discursos contra-hegemônicos sobre beleza em blogs na internet
}

Marcos Roberto Godoi

\begin{abstract}
Resumo: O objetivo deste estudo foi analisar os discursos (textos e imagens) sobre corpos femininos volumosos e estética em blogs na Internet. O corpus foi composto por imagens, textos e comentários de leitores, que foram analisados com base no materialismo cultural, na concepção dialógica de linguagem e na Análise do Discurso. Concluímos que os blogs apresentaram discursos contra-hegemônicos em relação ao padrão estético corporal da "beleza de mercado" e são espaços políticos e culturais de resistência, diálogo e fortalecimento do grupo de mulheres e homens que apreciam outra forma de ser bela.
\end{abstract}

Palavras-chave: corpos femininos. estética. discursos. blogs.

\section{INTRODUÇÃo}

Nas sociedades contemporâneas, via de regra, existem poucas referências que associem a beleza feminina ao corpo "gordo", "farto" ou "volumoso". Se pensarmos nos discursos sobre a beleza feminina hegemônicos em nossa cultura, ou mais especificamente na mídia, vamos encontrar predominantemente mulheres magras ou com o corpo definido e modelado como padrão estético de beleza ${ }^{1}$.

Conforme Goellner (2003a) existem várias pedagogias em circulação na sociedade. Assim, os filmes, músicas, revistas e livros,

\footnotetext{
"Professor da Rede Municipal de Ensino de Cuiabá. Membro do Grupo de Pesquisa Corpo, Educação e Cultura (COEDUC) da UNEMAT. Cuiabá, MT, Brasil. E-mail: mrgodoi78@hotmail.com 'O programa Fantástico, da Rede Globo, divulgou no dia 27 de dezembro de 2009 o lançamento do calendário/pôster "Mulheres Reais 2010" só com modelos acima do manequim 44, que faz parte do Projeto Mulheres Reais, com o objetivo resgatar e estimular a auto-estima de mulheres corpulentas.
} 
imagens, propagandas são também locais pedagógicos que estão a dizer de nós, seja pelo que exibem ou pelo que ocultam. Dizem também de nossos corpos e, por vezes, de forma tão sutil que nem mesmo percebemos o quanto somos capturadas/os e produzidas/os pelo que lá se diz.

Em nenhum momento histórico o corpo magro e esbelto esteve tão em destaque como nos dias atuais. Segundo Sudo e Luz (2007), o corpo nu ou vestido está definitivamente na moda, ele é exposto em revistas masculinas e femininas, revistas semanais brasileiras constantemente realizam matérias de capa abordando temas como: dietas; medo de engordar; estar/entrar em forma; a ciência em prol da saúde e do corpo.

De acordo com Fischler (1995, p. 69) "uma das características de nossa época é a lipofobia, sua obsessão pela magreza, sua rejeição quase maníaca à obesidade". Sob a moral da "boa forma", um corpo trabalhado, cuidado, sem marcas indesejáveis (rugas, estrias, celulites, manchas) e sem excessos (gorduras, flacidez) é o único que, mesmo sem roupas, está decentemente vestido. Além disto, a gordura e a flacidez ou a moleza são tomadas como símbolos da indisciplina, do desleixo, da preguiça, da falta de certa virtude, ou seja, da falta de investimento do indivíduo em si mesmo (GOLDENBERG; RAMOS, 2002). Para estes estudiosos, o corpo é um valor que identifica o indivíduo com um determinado grupo e, simultaneamente, o distingue de outros.

Por sua vez, Andrade (2003a) entende que o corpo é um constructo histórico, social e cultural, produzido de diversas formas em tempos e lugares diferentes. Podemos encontrar diversas representações de corpo na medicina, na biologia, na poesia, na cultura, na arte, na mídia, na esfera econômica e social. Nestas representações, há alguns tipos de corpos vistos como padrão, hegemônicos, porém existem também aqueles desviantes que insistem em fugir às regras. A representação segundo Andrade é um modo de produzir significados na cultura, através da linguagem e implicam relações de poder. No interior dessas relações de poder é que os 
grupos sociais são significados e representados. É nessas relações de poder que o corpo feminino é significado e representado na mídia, de um modo e não de outro, ou de múltiplas formas.

A mídia, a publicidade e a indústria da beleza tornaram o corpo um artefato do mercado econômico/social/cultural. Esse corpo do mercado de consumo é constantemente construído e reconstruído nos discursos midiáticos, adquire uma materialidade que é ao mesmo tempo, um produto do poder que gera divisões sociais. As relações de poder atuam sobre ou através dos corpos, em determinados contextos, produzindo efeitos de sentido, identidades sociais e culturais particulares (ANDRADE, 2003a).

Isto remete para a questão da hegemonia, de acordo com Williams (1979), trata-se do nível articulado superior de "ideologia", além disto, suas formas de controle não podem ser vistas apenas como "manipulação" ou "doutrinação". A hegemonia é sempre um processo ativo, todavia, não significa que seja sempre dominante. Nenhum modo de produção e nenhuma ordem social ou cultura dominante, nunca inclui ou esgota toda a prática, energia e intenção humanas. Sendo assim, há sempre espaços para resistências, disputas, subversões e impressão de novos significados e valores. Deste modo, é preciso acrescentar o conceito de contra-hegemonia e hegemonia alternativa que são elementos reais e persistentes da prática.

Com base nestas considerações, levantamos a seguinte pergunta de pesquisa: como são os discursos (textos e imagens) sobre a beleza feminina em corpos fartos em blogs que circulam na Internet? $\mathrm{O}$ objetivo desta pesquisa foi analisar tais discursos, buscando identificar posicionamentos contra-hegemônicos em relação ao padrão estético corporal (magro ou definido) hegemônico.

Neste trabalho, entenderemos por discurso "uma dispersão de textos cujo modo de inscrição histórica permite definir como um espaço de regularidades enunciativas" (MAINGUENEAU, 2005, p. 15). Partilhamos a consideração do primado do interdiscurso sobre o discurso, ou seja, a unidade pertinente de análise não é o discurso, mas o espaço de trocas enunciativas entre diversos discursos 
convenientemente escolhidos. Além disto, o discurso não deve ser pensado somente como um conjunto de textos, mas como uma prática discursiva, que pode ser considerada também, como uma prática intersemiótica que integra produções que pertencem a outros domínios semióticos (MAINGUENEAU, 2005). Sendo assim, imagens, fotografias, vídeos, figuras também podem ser consideradas discursos e não somente textos verbais.

Este trabalho localiza-se no campo denominado Estudos Culturais $^{2}$. De acordo com Nelson, Treichler e Grossberg (2001), este campo tem um longo compromisso com as populações sem poder, preocupando-se com o terreno cotidiano das pessoas e com todas as formas pelas quais as práticas culturais falam as suas vidas e de suas vidas. Envolve a observação de que as lutas em relação ao poder devem, de forma crescente, interagir e operar através das práticas culturais, da linguagem e da lógica do povo. Em termos metodológicos, os Estudos Culturais não têm nenhuma metodologia distinta, podendo ser entendida como uma bricolage, ou seja, a escolha da prática de pesquisa é pragmática, estratégica e auto-reflexiva, ela depende das questões que são feitas, e estas dependem do seu contexto (NELSON; TREICHLER; GROSSBERG, 2001). Sendo assim, o nosso referencial teórico/metodológico baseou-se no materialismo cultural ${ }^{3}$ de Raymond Williams, na concepção dialógica da linguagem de Mikhail Bakhtin ${ }^{4}$ e em contribuições da Análise do Discurso (AD).

\footnotetext{
${ }^{2}$ Os Estudos Culturais surgem com a fundação do Centre of Contemporary Cultural Studies (CCCS) na Universidade de Birmingham, em 1964 na Inglaterra, com o objetivo de estudar as formas, práticas e instituições culturais e suas relações com a sociedade e a transformação social.

${ }^{3} \mathrm{O}$ materialismo cultural é uma reelaboração da teoria marxista de cultura. Para Williams a cultura opera ativamente nas sociedades e não é um domínio separado ou instância autônoma de valores humanos (tradição idealista), ou uma instância que paira sobre a vida material em uma superestrutura que reflete a base (materialismo ortodoxo). Ao entender a cultura como força produtiva, o materialismo cultural coloca-a no mundo real, como uma consciência tão prática quanto a linguagem em que é veiculada e interpretada. Na era do capitalismo tardio, na qual cultura e economia estão claramente interligadas, trata-se de uma descrição muito mais adequada da produção cultural (CEVASCO, 2003).

${ }^{4}$ Bakhtin elaborou uma teoria marxista da linguagem, esta que passou a ser concebida como imanentemente social, ela existe assim, no sujeito e na história, nas práticas cotidianas, nas ações intersubjetivas, ou seja, na inexorabilidade (ontológica) da constituição dialógica do sujeito e da sociedade. Williams (1979) cita Bakhtin quando aborda seus conceitos de básicos para tratar da língua.
}

Movimento, Porto Alegre, v. 17, n. 03, p. 153-173, jul/set de 2011. 
Para o desenvolvimento da pesquisa, realizamos um levantamento de blogs sobre a estética feminina em corpos volumosos na Internet, no site de busca Google, entre dezembro de 2009 e janeiro de 2010. Foram encontrados onze blogs: Gordinhas maravilhosas; Cotidiano gordo; Beleza sem tamanho; Mulherão; Poderosas gordinhas; Grandes mulheres; Movimento plus size ; $^{5}$ Mundo GG; Toda gordinha; Gordinhas lindas; Confissões de uma gordinha. Depois, fizemos uma exploração nos blogs e selecionamos o corpus de análise, que foi composto por quatro textos, três comentários de leitores e quatro imagens em quatro blogs. A seleção do corpus foi arbitrária e levou em conta sua pertinência a questão de pesquisa.

Diversos/as pesquisadores/as têm se dedicado ao estudo das representações ou discursos sobre o corpo na mídia. Alguns deles analisam o corpo na mídia impressa (ANDRADE, 2003b, FIGUEIRA, 2003, SUDO; LUZ, 2007), outros analisam o corpo em um seriado televisivo e na publicidade (SILVA; GOMES, 2008; ARAÚJO; SANFÉLICE, 2008), respectivamente. Há também, estudiosas que buscam compreender os discursos sobre o corpo em blogs na Internet (AMARAL, 2008; FRIEDERICHS, 2008; e GARRINI, 2009). Ainda assim, não identificamos nenhum trabalho que aborda a questão dos corpos femininos volumosos em blogs, especificamente. Além disto, a relevância deste trabalho encontrase no fato de que o blog é um meio de comunicação que dá condições para que todos sejam produtores de cultura (veiculação de opiniões, valores, sentimentos etc.), não apenas uma versão escolhida por uma minoria (como por exemplo, os mass media). No entanto, sabemos que uma grande parcela da população ainda não tem acesso à Internet no Brasil, e no mundo.

${ }^{5}$ Plus size pode ser traduzido para o português como tamanho extra.

Movimento, Porto Alegre, v. 17, n. 03, p. 153-173, jul/set de 2011. 


\section{ANÁLISE DOS DISCURSOS E IMAGENS}

De início, a escolha (ideológica) das palavras nos título dos blogs chama a atenção: "maravilhosas", "lindas", "grandes", "poderosas". Estas palavras funcionam como modalizações apreciativas, expressando elogios para qualificar o corpo volumoso. Conforme Bakhtin (1997, p. 36), "a palavra é o fenômeno ideológico por excelência". Nela é que melhor se revelam as formas básicas e ideológicas gerais da comunicação semiótica. Deste modo, o fato de escolher uma palavra em detrimento de outra, é um fato ideológico, dos sentidos que se pretende mobilizar.

Sobre a estrutura dos blogs, eles são compostos de posts ou artigos sobre temáticas que versam sobre o cotidiano, auto-estima, moda, ou estética de corpos fartos e também comentários dos leitores/ seguidores. Podemos encontrar ainda fotos, vídeos de filmes ou videoclipes, reprodução de obras de arte e ilustrações com mulheres corpulentas. Há links para outros blogs relacionados ao mesmo tema e dos seguidores dos blogs. Encontramos ainda, divulgação de propagandas de empresas que vendem produtos e serviços destinados às mulheres corpulentas.

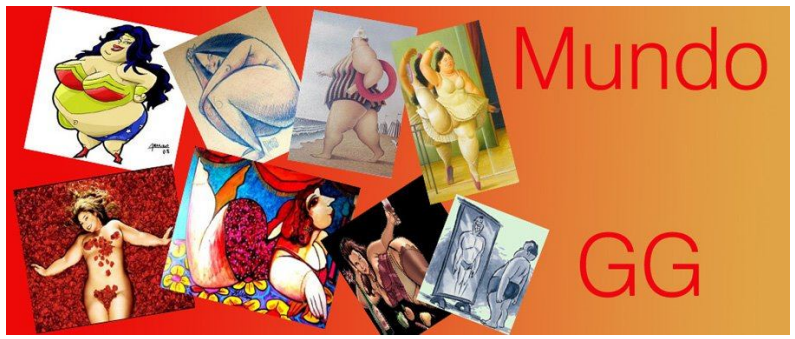

Figura 1: Ilustração do blog "Mundo GG"

Fonte: blog Mundo GG

Esta ilustração contém obras de arte, fotografias e desenhos, como por exemplo, a Mulher Maravilha volumosa e a mulher nua deitada em uma cama com pétalas de rosa vermelhas (referência a uma cena do filme Beleza Americana). Todas estas imagens visam 
reforçar e valorizar positivamente a estética do corpo farto. Se na grande mídia são escassas as referências sobre a beleza feminina em tamanho grande, o blog se constitui então como um espaço de resistência à estética da magreza e a emergência de um corpo feminino volumoso ressignificado como signo de beleza. De acordo com Bakhtin (1997), até mesmo os signos não-verbais banham-se no discurso e não podem ser separadas dele. A palavra está presente em todos os atos de compreensão e interpretação, mas isto não quer dizer que ela possa substituir qualquer outro dos signos ideológicos. Assim, constatou-se uma complementaridade entre as imagens e os textos nos discursos analisados, que ajudam a reforçar os significados em torno da beleza dos corpos fartos.

Oi pessoal, criei uma seção nova no blog que vai se chamar GGaleria de Arte.
Aqui pretendo colocar imagens, fotografias, desenhos ou qualquer expressão
de arte que exalte a nossa beleza GG de cada dia. Procurem sempre nos
marcadores por matérias novas com esse tema, porque uma coisa é fato: o
mundo gg está em expansão (e olha que eu nem me refiro a esse blog,
rsrs) e apesar de ainda sermos um número pequeno a tendência é ouvir
cada vez mais palavras como GG, plus size como tantas outras que
designam a parte da população que não está no padrão Barbie de
viver. [...]. (grifos nossos)

Quadro 1: Blog "Mundo GG"

Fonte: link "GGaleria de arte" Postado em: 7 dez. 2009, por Ana.

A expressão "exalte nossa beleza GG de cada dia" faz um interdiscurso ${ }^{6}$ de forma estilística com o trecho da oração do Pai Nosso, "o pão nosso de cada dia". O pão (alimento) significa algo que é essencial para a vida. Assim, a beleza significa algo que também seria essencial para as mulheres volumosas. A expressão destacada funciona como uma modalização apreciativa neste discurso, para valorizar positivamente a estética das mulheres corpulentas. Conforme Bakhtin (1997), na enunciação viva, cada elemento contém ao mesmo tempo um sentido e uma apreciação. A significação

\footnotetext{
${ }^{6}$ Sobre o interdiscurso, Maingueneau (2002) destaca que o discurso só adquire sentido no interior de um universo de outros discursos, lugar no qual ele deve traçar seu caminho. Para interpretar qualquer enunciado, é necessário relacioná-lo a outros enunciados que são comentados, parodiados, citados etc.
} 
objetiva forma-se graças à apreciação, pois ela indica que uma determinada significação entrou no horizonte imediato dos interlocutores, e no horizonte social mais amplo de um determinado grupo social. Além disto, a apreciação é responsável pelo papel criativo nas mudanças de significação, esta que é no final das contas uma reavaliação, ou seja, o deslocamento de uma palavra determinada de um contexto apreciativo para outro. Assim, no discurso em análise, há um subentendido que aponta para a mudança de significado de gorda $=$ feia, para gorda $=$ bonita .

De acordo com o materialismo cultural de Williams (1979), esta concepção de estética, apresenta-se como uma formação cultural emergente, que destoa do padrão estético dominante ou hegemônico de beleza feminina pautado na magreza, tal qual o modelo da boneca Barbie, mencionado no discurso em foco. As formações emergentes compõem-se dos novos significados e valores, novas práticas, novos tipos de relações que estão sendo continuamente criados.

Sobre as disputas em torno das significações, Bakhtin (1997) esclarece que os novos aspectos da existência que foram integrados no círculo de interesse social, que se tornaram objetos da fala e da emoção humana, não coexistem pacificamente com os elementos existentes anteriormente; pelo contrário, entram em luta com eles, submetem-nos a uma reavaliação, fazem-nos mudar de lugar no interior da unidade do horizonte apreciativo. Essa evolução dialética reflete-se na evolução semântica.

A expressão "o mundo gg está em expansão..." representa uma hipérbole, ou seja, uma figura de linguagem que proclama uma ideia de forma exagerada. Entendemos que o âmbito de circulação dos discursos dos blogs é ainda é restrito, e que para transformar os significados sociais na esfera mais ampla da sociedade e da cultura há um longo caminho. No entanto, é um indicativo de que há significados divergentes à estética hegemônica circulando na sociedade.

Neste mesmo blog em análise, a autora da postagem apresenta um artista chamado Les Toil, que faz desenhos de pin-ups gordinhas. 


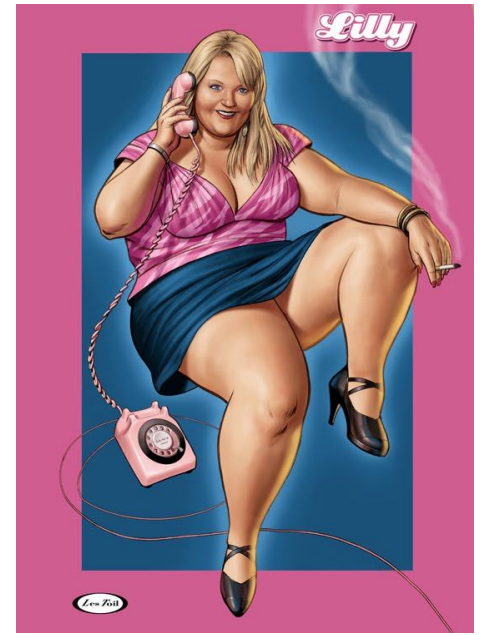

Figura 2: Pin-up Lilly - Les Toil

Fonte: blog Mundo GG

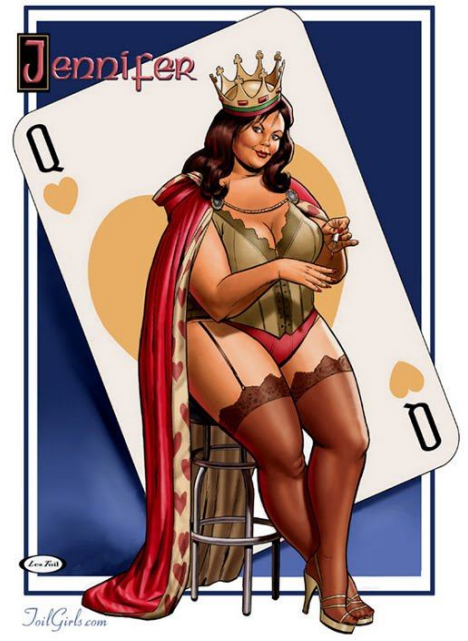

Figura 3: Pin-up Jennifer - Les Toil Fonte: blog Mundo GG

O termo pin-up surgiu na década de 40 e se refere a fotografias, desenhos, pinturas ou ilustrações de mulheres consideradas símbolos sexuais. Tais fotos ou ilustrações apareciam frequentemente em calendários, os quais eram produzidos para serem pendurados (em inglês, pin up). Posteriormente, posters de "pin-up girls" começaram a ser produzidos em massa. As pin-ups são elementos culturais residuais do passado, que ainda estão presentes na dinâmica cultural do presente. Mas agora, são ressignificadas com corpos volumosos. Segundo Williams (1979), a estruturação residual é tudo aquilo que foi efetivamente formado em um tempo passado, mas ainda está ativo no processo cultural do presente. O residual pode ter uma relação alternativa, oposta ou incorporada à cultura dominante.

Estas imagens, construídas como signo de beleza feminina, parecem apontar para o imperativo da sensualidade e erotização das mulheres, com vistas a despertar o desejo do outro. Conforme Goellner (2003b, p. 54) "valorizada pela aparência do seu corpo é ao prazer do outro que deve agradar, ainda que nesse jogo de sedução não seja avara consigo mesma, exercitando também seu desejo, sua sexualidade e sua feminilidade". 
AEEEEE o blog FINALMENTE está no ar!!!! EEEEEEEE Felicidades e comemorações a parte, o post de hj e sobre uma iniciativa SENSACIONAL! É a NOW Foundation que é a fundação que luta pelos direitos das mulheres nos EUA. Entre esses direitos existe o direito de SE AMAR! Porque ninguém precisa ter o corpo que a mídia idealiza como bonito para ser feliz. Como vivemos na era da estética, se sentir bem consigo mesmo é um dos primeiros passos para ter uma vida feliz, então nada melhor que a campanha Love your Body (Ame seu corpo)! Essa imagem ai embaixo traduz muito bem a idéia da campanha: (cartaz) Vamos aderir? (grifo nosso).

Quadro 2: Blog "Movimento plus size"

Fonte: post "Now Foundation" Postado em: 24 dez. 2009, por Marina Melino

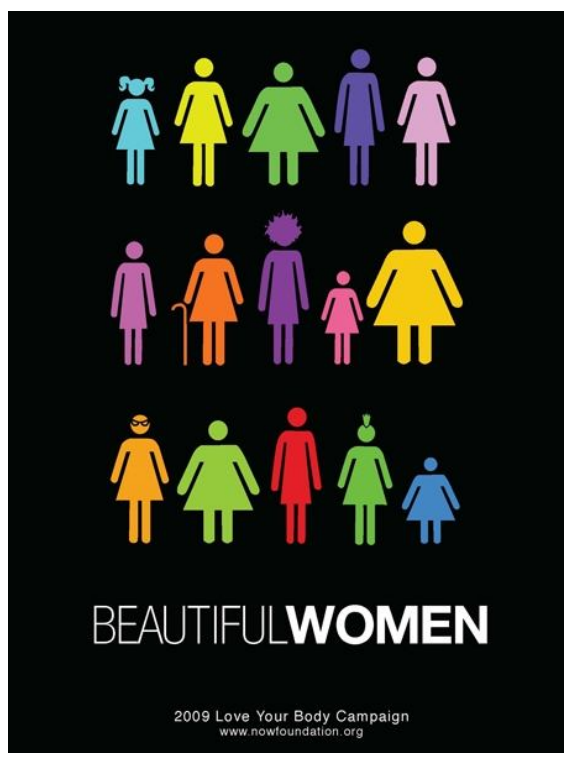

Figura 4: Cartaz da campanha Love your body Fonte: BLOG Movimento plus size

Através do discurso indireto $(\mathrm{DI})^{7}$, a enunciadora cita a campanha de valorização do corpo feminino, promovida por uma Associação dos Estados Unidos, estabelecendo assim, um diálogo com outro discurso. Para Bakhtin (1997), o diálogo precisa ser

\footnotetext{
${ }^{7}$ No discurso indireto, o enunciador citante tem uma infinidade de formas para traduzir as falas citadas, pois não são as palavras exatas que são relatadas, mas sim o conteúdo do pensamento (MAINGUENEAU, 2002).
} 
entendido num sentido amplo, não apenas entre pessoas colocadas face a face, mas qualquer tipo de comunicação verbal. $\mathrm{O}$ discurso escrito é parte integrante de uma discussão ideológica em grande escala, pois ele pode responder alguma coisa, refutar, antecipar as respostas e objeções potenciais, procurar apoio etc. No caso do discurso em análise, a enunciadora apóia, divulga e promove a campanha da associação feminista estadunidense aqui no Brasil, convidando as/os leitoras/es para aderir.

É possível perceber um distanciamento crítico em relação ao padrão de beleza divulgado na mídia: "ninguém precisa ter o corpo que a mídia idealiza para ser feliz". Além disto, a enunciadora defende a auto-estima das mulheres, através de um tipo de discurso didático "um dos primeiros passos para se sentir feliz é..." e de militância, haja vista a pergunta que finaliza a sequência discursiva, as expressões "campanha", "direitos das mulheres" e "direito de SE AMAR".

O cartaz pode ser entendido no discurso como um intertexto. Conforme Maingueneau (2000), a intertextualidade supõe a presença de um texto em um outro, no caso estudado, através da reprodução do cartaz no blog. No que se refere aos signos não-verbais, pode-se ver a representação de vários tipos de corpos (signos plásticos) de mulheres - baixas, altas, magras, gordas, crianças, adultas, idosas, deficientes (visto óculos e bengala) - em várias cores, dando assim um sentido de diversidade, de que existem várias formas de ser bela.

[...] Ser gordinha foi durante muito tempo um problema pra mim, mas hoje em dia é algo que não me incomoda em nada. Muito pelo contrario, reforça a minha indentidade (sic.), e a minha personalidade individualista. Não quero jamais me ver obrigada a seguir um padrão estabelecido por quem quer que seja! Quero poder ser eu mesma! Me considero uma mulher bonita, mesmo sendo gordinha. $E$ faço tudo o que todo mundo faz, mesmo sendo gordinha. E modestia (sic.) parte, faço muito bem. ;)" :B Espero que tenham gostado! Beijos e até a próxima! (grifo nosso)

Quadro 3: Blog "Toda gordinha: aqui, a exuberância é beleza" Fonte: post "Capa da semana" Postado em 30 de dezembro de 2009, por Lara Fernandes 
Na primeira pessoa do singular, a enunciadora faz um autorelato da sua relação com seu corpo. Ela confessa que antes esta relação era problemática, mas que passou a se aceitar e a se valorizar. Além disto, ela rejeita os padrões estéticos estabelecidos (vide a sequência grifada), e se considera bonita com o corpo que tem. Fica evidente que as mulheres não são meros objetos nos quais se direcionam os padrões estéticos e comportamentais. Elas interagem no seu tempo com estes padrões, e aprendem diferentes maneiras de ser bela e feminina, elas tanto podem se reconhecer e se assumir nestes padrões ou não (GOELLNER, 2003b). Este discurso se enquadra nas formações culturais emergentes em relação ao padrão estético feminino, sendo oposicionista ao modelo de beleza (do corpo magro) dominante.

Silvio Junior Wencevoski disse...
Você não é gordinha, te achei linda e gostosa (sinceridade acima de tudo). Parabéns
pelo blog, muito bem feito e conduzido, que você tenha um grande sucesso em 2010.
Lindona, beijos! 30 de dezembro de 2009 05:14
Natália coelho disse...
Acho legal você ser feliz do jeito que você é. E eu até acho engraçado como todo
gordinho tem o rosto lindo. Incrível. Bom,eu também sou uma gordinha, to pouco acima
do peso, e ao contrário de você, não estou feliz com isso. Acho que cada um tem que
procurar estar bem consigo e é isso que eu vou fazer. Abraços. 30 de dezembro de
$200909: 28$
Vini disse...
Primeiro parabenizar pelo blog que ainda n conhecia. Depois dizer que o blog é d super
bom gosto e concordo com tudo que li. As pessoas esquecem de ser felizes pq
querem viver o que a TV vende, o que está na capa das principais revistas. Saber
vive é independente de peso, raça ou qualquer outra coisa. Gosto de mulheres que
chamo de gostosas. Que tem onde pegar! Não gosto de osso, gosto de carne. E gosto
de bom humor. Que vocês tem d+! Parabens (sic.) novamente!! 3 de janeiro de 2010
$09: 34$ (grifo nosso)

Quadro 4: Blog "Toda gordinha" - Comentários do post anterior

No que tange ao processo de compreensão do discurso do outro, Bakhtin (2003) esclarece que o ouvinte (ou leitor), ocupa simultaneamente uma posição responsiva ativa em relação a ele: concorda ou discorda (total ou parcialmente), completa-o, aplica-o, 
prepara-se para usá-lo etc. Toda compreensão do enunciado vivo é de natureza ativamente responsiva, embora o grau de ativismo seja bastante diverso. Deste modo, Silvio fez vários elogios à Larissa (enunciadora), parabenizou o trabalho com o blog e desejou sucesso. Natália concordou com a enunciadora, confessou que não está feliz com o corpo que tem, mas que tentará se sentir bem consigo mesma. Vini elogia o blog e em seguida faz uma crítica às pessoas que querem seguir um padrão de consumo e de beleza divulgado pela mídia (vide trecho em destaque). Ele elogia quem sabe viver independentemente das características físicas. Diz que prefere mulheres volumosas, "que tem onde pegar" e que tenham bom humor. Termina o enunciado parabenizando-a.

Conforme Carvalho e Martins (2006, p. 218), "o mito do sucesso profissional e amoroso, a partir de um modelo idealizado de beleza (ou de aparência) é desmistificado na vida real e singular de cada um, na realização efetiva de cada corpo". Apesar dos preconceitos existentes e por mais que o corpo volumoso para mulheres não seja hegemônico em nossa cultura, há pessoas que se interessam e admiram esta forma de beleza.

\begin{abstract}
Esse período em que nos gordos finalmente recebemos uma pontinha do que realmente devemos ter que foi um espaço de divulgação na mídia esta causando uma mudança na psique de uma porcentagem de gordinhos e gordinhas que antes eram praticamente zerados de auto-estima, fato que me deixa de certo feliz, embora tenha eu algumas coisas contra a forma em que estão colocando a beleza em primazia, quando é reconhecido que a aceitação física é formada por vários aspectos. Entendo que quase toda mulher tem uma necessidade em especial de se sentir bela, mas não é só a beleza momentânea de vestidos e maquiagens demonstrada nos programas e entrevistas que formam um ser belo, para uma pessoa gorda sentir verdadeiramente que é bonito e desejado é preciso bem mais que estar bem vestido e maquiado, e onde fica a auto-aceitação, do que adianta se sentir lindo num momento e em seguida olharse ao espelho e repugnar a imagem refletida. Acredito que assim como a mídia enfatizou e enfatiza que a beleza provem de um corpo magro, esta sendo feita um divulgação de uma beleza momentânea. Não sou contra o glamour do momento afinal também gosto de vestir para arrasar e me sentir bem vestida, só vejo da seguinte forma o espaço que esta sendo cedido nas vias de comunicação deveria ser mais bem utilizado (grifos nossos).
\end{abstract}

Quadro 5: Blog "Cotidiano gordo"

Fonte: post "Não só de moda vive o gordo" Postado em: 16 dez. 2009, por Milly. 
Para Bakhtin (2003), o falante não é um Adão bíblico, e por isto o objeto de seu discurso se torna um palco de encontro com opiniões de interlocutores imediatos ou no campo da comunicação cultural através de pontos de vista, visões de mundo, correntes, teorias etc. Deste modo, a enunciadora apresenta um ponto de vista bastante crítico em relação ao espaço que está sendo dado na mídia para os gordinhos: "colocando a beleza em primazia". Ela discorda da forma de beleza efêmera baseada no consumo de produtos da indústria da beleza e da moda: "beleza momentânea". Conforme Wolf (1992), o que incomoda as mulheres no mito da beleza não são os enfeites, a expressão da sexualidade, o tempo gasto se arrumando ou o desejo de conquistar alguém, mas a luta é entre a dor e o prazer, a liberdade e a obrigação. Percebe-se aqui, que este discurso pertence a uma formação cultural emergente, oposicionista ao padrão estético dominante, pois apresenta outros valores como fundamentais, conforme podemos verificar na continuidade de seu discurso:

Quando se tem uma vasta gama de necessidades a serem discutidas, tais como a
marginalização do gordo como individuo social, temos casos seqüenciados de
leitores em diversos blogs e sites queixando-se de serem destratados em espaços
públicos, em ambientes de trabalho e mesmo dentro de casa no âmbito familiar.
Deveriam ser abordados temas dos quais vivenciamos dia a dia como a necessidade
de mostrarmos que somos tão capazes como qualquer outra pessoa e tirar a
imagem de sermos indivíduos preguiçosos e de gula imensurável, mostrar que
lutamos hora a peso hora contra piadas mal intencionadas, precisamos esclarecer
ao meio social que estamos em todos os lugares e que com todo preconceito
desmedido e sem vergonha que vive explicitado em nossos rostos ainda assim
acordamos para viver o dia seguinte mesmo quando não há a mínima vontade de
sair da cama com medo do que iremos ouvir, ver e sentir no caminho ao trabalho.
É esse tipo de coisa que deveria ser discutida e mostrada perante a mídia, com uma
finalidade básica a aceitação a cima de tudo para que assim nossas crianças não
tenham medo de serem gordinhas por não quererem ser ridicularizadas pelos
coleguinhas se tornando futuros anoréxicos. A luta contra a demonização do
gordo é que necessita de espaço na mídia, vestidos, biquínis e maquiagem são
importante mas não fazem a sociedade raciocinar e mudar a maneira de tratar seu
próximo. Acho louvável a iniciativa e também acho valida a aparição de modelos
"Plus Size" na mídia, mas não podemos esquecer que não só de Moda e Beleza vive
o ser humano (grifo nosso).

Quadro 6: Post "Não só de moda vive o gordo" - continuação

Postado em 16 de dezembro de 2009, por Milly 
A enunciadora destaca aspectos importantes vivenciados pelas pessoas gordas, tais como a discriminação na família, na escola, no trabalho, e defende que estas coisas que deveriam ser mostradas na mídia para que os gordos pudessem se aceitar mais e lutar contra o preconceito. A gordura frequentemente associada com feiúra sofre uma das maiores formas de discriminação nas sociedades que cultuam o corpo. "Discriminação ostensiva, manifesta e sem culpa, ao contrário dos negros, pobres, gays ou qualquer outra minoria discriminamos os feios e/ou gordos sem nenhum pudor ou vergonha" (NOVAES; VILHENA, 2003, p. 32).

Para a enunciadora, a beleza não pode ser momentânea, baseada na moda, em maquiagem e roupas, pois estas coisas não fazem a sociedade mudar a forma de tratar seu próximo, apontando para a ética no trato com o ser humano. Neste sentido, Bakhtin (2003) destaca que o enunciado é pleno de tonalidades dialógicas, porque a nossa própria idéia nasce e se forma no processo de interação e luta com o pensamento dos outros. A enunciadora também é propositiva quando diz que "a luta contra a demonização do gordo que necessita de espaço na mídia", e embora elogie a iniciativa da aparição modelos com corpos volumosos na mídia, destaca que "não só de Moda e Beleza vive o ser humano".

\section{Considerações Finals}

Nos discursos analisados foram verificadas disputas em torno dos significados de beleza feminina, com uma valorização das mulheres com corpos volumosos ou fartos como signos de beleza. Sobretudo constatamos a construção de sentidos de beleza, funcionando como discursos contra-hegemônicos à estética do corpo magro e modelado para representar a beleza feminina (padrão estético hegemônico).

Foram identificado pontos de vista críticos em relação aos padrões de beleza, mesmo quando estes se referem às mulheres gordas, pois muitas vezes os discursos direcionam as mulheres para a indústria da beleza e para o consumismo (roupas, maquiagem, 
moda etc.), com o pretexto de deixar a mulher bela. Deste modo, a "beleza de mercado", mesmo para mulheres corpulentas pode ser entendida como uma concessão da formação cultural dominante e do mercado capitalista, este que, pretende vender, cada vez mais. Nesta perspectiva, as "práticas sociais são moldadas por relações regidas por um sistema de produção que privilegia o lucro em detrimento do valor humano" (CEVASCO, 2003, p. 167). Neste sentido, constatamos a interligação dos aspectos culturais e econômicos nos discursos analisados.

Contudo, uma cultura ou uma hegemonia não é totalitária e totalizante, há sempre margens para emergir novos significados. "Mesmo quando as mensagens mais poderosas, mais controladoras, estão dominantes, elas têm ainda que se defrontar com a "palavra" de resposta do espectador e com o mundo da experiência" (NEWCOMB, 2010, p. 384). Nos termos do materialismo cultural podê-se constatar que os discursos sobre a beleza feminina em corpos fartos é uma formação cultural emergente na sociedade contemporânea. Todavia tende a se incorporar à formação cultural dominante no caso da beleza de mercado (do consumismo, da indústria da beleza e da moda), mas também apresenta significados oposicionistas, questionando os padrões estabelecidos (mesmo para mulheres gordas), e apresentam outro conceito de beleza, muito mais vinculado às características pessoais do que físicas (valor humano). Deste modo, os blogs são espaços importantes de resistência, diálogo, debates, questionamento, disputas de significados e fortalecimento do grupo de mulheres e homens que apreciam uma forma diferente de ser bela.

No que tange às implicações para a área do conhecimento de Educação Física, no nível da prática pedagógica, os/as professores/ as podem sistematizar atividades buscando refletir sobre as relações entre corpo, estética e saúde, tais como: leitura crítica de revistas, programas televisivos, filmes, publicidades, dentre outras mídias; produção de dramatizações, cartazes, história em quadrinhos, painéis ou blogs; realização de seminários e debates, etc. Seria possível discutir com os estudantes algumas questões específicas, tais como: 
O que é um corpo belo? A beleza está vinculada somente a atributos físicos? Quais os padrões estéticos corporais em diferentes momentos históricos, e em diferentes culturas? Quem tem o poder de definir o que é um corpo belo? Que tipos de corpos femininos e/ou masculinos são mais divulgados e valorizados na mídia? Quais corpos são ocultados ou menos visíveis na mídia, e como eles são representados? Quais são os riscos da vaidade em excesso para a saúde? Ter um corpo magro significa necessariamente ter mais saúde, ou ter um corpo fora do padrão estético, significa necessariamente não ter saúde? Quais as relações entre beleza e consumismo? Estes são apenas alguns apontamentos pedagógicos que podem contribuir para uma prática pedagógica baseada na crítica cultural. 
Female body bulky and aesthetics: counterhegemonic discourses beauty in blogs on the internet

Abstract: The aim of this study was to analyze the speeches (text and images) on female bodies bulky and aesthetics on Internet blogs. The corpus was composed of images, texts and reader comments, which were analyzed based on cultural materialism, the dialogic conception of language and Discourse Analysis. We conclude that the blogs had counterhegemonic discourse in relation to body aesthetic standard of "beauty market" and are political and cultural spaces of resistance, and strengthening dialogue among the women and men who enjoy another way to be beautiful.

Keywords: female bodies. aesthetics. speeches. blogs.

Cuerpos femininos voluminosos y estética: discursos contra-hegemónicos acerca de belleza en blogs en internet

Resumen: El objetivo de este estudio fue analizar los discursos (textos e imágenes) sobre los cuerpos femininos voluminosos y la estética en los blogs de Internet. El corpus se compone de imágenes, textos y comentarios de los lectores, que se analizaron con base en el materialismo cultural, la concepción dialógica del lenguaje y el Análises del Discurso. Llegamos a la conclusión de que los blogs había discurso contrahegemónico en la relación a la norma estética del cuerpo del "mercado de la belleza" y son espacios políticos y culturales de la resistencia, y el fortalecimento del diálogo entre los hombres y mujeres que disfrutan de outra manera de ser hermosa.

Palabras clave: cuerpos femeninos. estética. discursos. blogs. 


\section{REFERÊNCIAS}

AMARAL, Marcela. O fenômeno do culto ao corpo moderno e a magreza como símbolo de beleza: estudo sobre o movimento pró-Ana no Brasil. In: VI CONGRESSO PORTUGUÊS DE SOCIOLOGIA, 6., 2008, Lisboa. [Anais...] Lisboa: Universidade Nova de Lisboa 2008. p. 1-10.

ANDRADE, Sandra dos Santos. Saúde e beleza do corpo feminino: algumas representações no Brasil do século XX. Movimento, Porto Alegre, v. 9, n. 1, p. 119-143, jan./abr. 2003a.

. Mídia impressa e educação de corpos femininos. In: LOURO, G. L.; NECKEL, J. F.; GOELLNER, S. V. (Org.). Corpo gênero e sexualidade: um debate contemporâneo na educação. Petrópolis, RJ: Vozes, 2003b. p. 108-123.

ARAÚJO, Denise Castilhos de; SANFÉLICE, Gustavo Roese. Real beleza Dove: preocupação com a saúde ou estratégia publicitária? Gestão e Desenvolvimento, Novo Hamburgo, v. 5, p. 121-128, 2008.

BAKHTIN, Mikhail. Marxismo e filosofia da linguagem: problemas fundamentais do método sociológico na ciência da linguagem. 8. ed. São Paulo: Hucitec, 1997.

Estética da criação verbal. 4. ed. São Paulo: Martins Fontes, 2003.

COTIDIANO gordo: blog. Disponível em: <http://cotidianogordo.blogspot.com/>. Acesso em: 20 dez. 2009.

CARVALHO, Maria Cláudia; MARTINS, André. A obesidade como objeto complexo: uma abordagem filosófico-conceitual. In: BAGRICHEVSKY, Marcos; PALMA, Alexandre; ESTEVÃO, A. (Org.). A saúde em debate na Educação Física. Blumenau: Nova Letra, 2006. v.2, p. 203-222.

CEVASCO, Maria Elisa. Dez lições sobre estudos culturais. São Paulo: Boitempo, 2003.

FISCHLER, Claude. Obeso benigno, obeso maligno. In: SANT'ANNA, Denise B. (Org.). Políticas do corpo: elementos para uma história das práticas corporais. São Paulo: Estação liberdade, 1995. p. 69-80.

FIGUEIRA, Márcia Luiza Machado. A revista Capricho e a produção de corpos adolescentes femininos. In: LOURO, Guacira Lopes, NECKEL, Jane Felipe, GOELLNER, Silvana Vilodre. (Org.). Corpo, gênero e sexualidade: um debate contemporâneo na educação. Petrópolis-RJ: Vozes, 2003. p. 124-135.

FRIEDERICHS, Marta Cristina. Corpos escritos na internet: representações do corpo em blogs. Fazendo Gênero, Florianópolis, p. 1-7, ago. 2008. 
GARRINI, Selma Peleias Felerico. O corpo construído na Web 2.0: uma análise das mensagens corporais veiculadas em blogs femininos no período de 2008 a 2009. In: SIMPÓSIO NACIONAL ABCIBER, 3., 2009, São Paulo, 2009. [Anais...] p. 1-13.

GOELLNER, Silvana Vilodre. A produção cultural do corpo. In: LOURO, Guacira Lopes; NECKEL, Jane Felipe; GOELLNER, Silvana Vilodre. (Org.). Corpo gênero e sexualidade: um debate contemporâneo na educação. Petrópolis, RJ: Vozes, 2003a. p. 28-40.

Bela, maternal e feminina: imagens da mulher na Revista de Educação Physica. ljuí-RS: EdUnijuí, 2003b.

GOLDENBERG, Mirian; RAMOS, Marcelo Silva. A civilização das formas: o corpo como valor. In: GOLDENBERG, Mirian (Org.). Nu e vestido: dez antropólogos revelam a cultura do corpo carioca. Rio de Janeiro: Record, 2002. p. 19-40.

MAINGUENEAU, Dominique. Análise de textos de comunicação. 2. ed. São Paulo: Cortez, 2002.

Gênese dos discursos. Curitiba: Criar Edições, 2005.

Termos-chave da análise do discurso. Belo Horizonte: EdUFMG, 2000.

MOVIMENTO Plus Size: blog. Disponível em: shttp://www.movimentoplussize.com/ z. Acesso em: 27 dez. 2009.

MUNDO GG. Disponível em: <http://mundogege.blogspot.com/>. Acesso em: 27 dez. 2009.

NELSON, Cary; TREICHLER, Paula A.; GROSSBERG, Lawrence. Estudos culturais: uma introdução. In: SILVA, Tomaz Tadeu da (Org.). Alienígenas em sala de aula: uma introdução aos Estudos Culturais em educação. 3. ed. Petrópolis-RJ: Vozes, 2001. p. 7-38.

NEWCOMB, Horace. Sobre os aspectos dialógicos da comunicação de massa. In: RIBEIRO, Ana Paula Goulart; SACRAMENTO, Igor (Org.). Mikhail Bakhtin: linguagem, cultura e mídia. São Carlos-SP: Pedro e João Editores, 2010. p. 359-387.

NOVAES, Joana V.; VILHENA, Junia de. De cinderela a moura torta: sobre a relação mulher, beleza e feiúra. Interações, v.8, n. 15, jan./jun. 2003. p. 9-36.

SILVA, Pierre Normando Gomes da; GOMES, Eunice Simões Lins. Eternamente jovem: corpo malhado, ficção televisional e imaginário. Pensar a Prática, Goiânia, v. 11 , n. 2 , maio-ago. 2008 , p. $197-207$. 
SUDO, Nara; LUZ, Madel T. O gordo em pauta: representações sobre o ser gordo em revistas semanais. Ciência e Saúde Coletiva, v. 12, n. 4, p. 1033-1040, 2007.

TODA gordinha: aqui a exuberância é beleza!, blog. Disponível em: <http:// www.todagordinha.blogspot.com/>. Acesso em: 3 jan. 2010.

WILLIAMS, Raymond. Marxismo e literatura. Rio de Janeiro: Zahar, 1979.

WOLF, Naomi. 0 mito da beleza: como as imagens de beleza são utilizadas contra as mulheres. Rio de Janeiro: Rocco, 1992.

Endereço para correspondência:

Marcos Roberto Godoi

Rua A, n. 107, Res. Cristal, BI B2, apto. 65, bairro Terra Nova,

CEP 78050-400, Cuiabá-MT.

Recebido em: 23.06.2011

Aprovado em: 07.10.2011 
